\title{
Diazoxide-resistant focal hyperinsulinism due to SUR1 deficiency
}

INSERM

\section{Source}

INSERM. (1999). Orphanet: an online rare disease and orphan drug data base. Diazoxideresistant focal hyperinsulinism due to SUR1 deficiency. ORPHA:276598

A rare, congenital, isolated hyperinsulinism disorder characterized by diazoxide unresponsive recurrent episodes of hyperinsulinemic hypoglycemia resulting from an excessive insulin secretion by the pancreatic bêta-cells due to SUR1 deficiency. Hypoglycemia may lead to variable clinical manifestations, ranging from asymptomatic hypoglycemia revealed by routine blood glucose monitoring to macrosomia at birth, mild to moderate hepatomeg aly and life-threatening hypoglycemic coma or status epilepticus, further leading to poor neurological outcome. 